\title{
MULTIPLE INTRACRANIAL MENINGIOMAS
}

\author{
Diagnosis, biological behavior and treatment
}

\author{
José Carlos Lynch', Leandro Alcy Sales Ferreira ${ }^{2}$, Leonardo Welling ${ }^{2}$, Renata Cardoso Schulz ${ }^{3}$
}

\begin{abstract}
Multiple intracranial meningiomas (MIM) are a rare pathology when not associated with neurofibromatosis. The prevalence rate of those tumors varied from 2.3 to $8.9 \%$ of all intracranial meningiomas. Objective: To present, analyze and discuss the cases of seven patients diagnosed with multiple intracranial meningiomas, describing their clinical and histological characteristics, as well as their biological behavior. Method: The patients records, surgical descriptions, imaging studies and the histopathological exams were retrospectively reviewed. This is the largest series of MIM publisted in Brazil. Results: This sample consists of five women and two men. The age varied from 42 to 84 (average 53.8). Twenty-two meningiomas were identified and varied from 1.5 to $192 \mathrm{~cm}^{3}$, with an $62.8 \mathrm{~cm}^{3}$ average volume. The number of procedures varied from 1 to 5 per patient. No surgical death occurred in this series. Conclusion: Despite the multiplicity of tumors, number of recurrences, the new tumors, repeated operations and re-operations, radiotherapy and a number of postoperative complications, the patients experienced a long survival in conjunction with a fairly good quality of life.
\end{abstract}

KEY WORDS: brain tumors, meningiomas, multiple intracranial meningiomas, microneurological surgery.

\section{Meningiomas intracranianos múltiplos: diagnóstico, comportamento biológico e tratamento}

Resumo - Os meningiomas intracranianos múltiplos são tumores raros quando não associados a neurofibromatose, correspondem de 2,3 a 8,9\% de todos os meningiomas intracranianos. Objetivo: Apresentar, analisar e discutir 7 pacientes com diagnóstico de meningioma intracraniano múltiplo, descrevendo as características clínicas, histológicas e o comportamento biológico desses tumores. Método: Trata-se de revisão retrospectiva incluindo a análise dos prontuários, das descrições cirúrgicas, dos estudos de imagem e do material histopatológico. Esta série é a maior série de meningiomas intracranianos múltiplos publicada no Brasil. Resultados: A casuística é composta de 5 mulheres e 2 homens. A idade oscilou entre 42 e 84 anos, com média de 53,8 anos. Identificamos 22 meningiomas que variaram de 1,5 a $192 \mathrm{~cm}^{3}$, com volume médio de $62,8 \mathrm{~cm}^{3}$. O número de procedimentos oscilou de 1 a 5 por paciente. Não ocorreu mortalidade cirúrgica. Conclusão: Apesar de vários tumores, de recorrências, do surgimento de novas neoplasias, de várias cirurgias, re-operações, do tratamento com radioterapia e de inúmeras complicações pós-operatórias, esses pacientes obtiveram uma longa sobrevida com boa qualidade de vida.

PALAVRAS-CHAVE: tumor cerebral, meningiomas, meningiomas intracranianos múltiplos, microneurocirurgia.

Meningiomas are tumors originated from arachnoidal cells present in the villi, in the granulations, in the stroma of the perivascular spaces and in the choroid plexus; corresponding to 13 to $20 \%$ of all intracranial tumors ${ }^{1-3}$.

Multiple intracranial meningiomas (MIM), when not associated with neurofibromatosis, are a rare event, which corresponding to 2.3 to $8.9 \%$ of all intracranial meningiomas ${ }^{4-11}$.

The multiple intracranial meningiomas terminology should be used only when two or more meningiomas occur either simultaneously or sequentially in different loca- tions. It is important to establish the difference between this pathology and tumor recurrence or diffuse meningiomatosis $^{1,3,4,7-10}$

Our study aims presenting, analyzing and discussing 7 patients diagnosed with multiple intracranial meningiomas, describing their clinical, radiological, and histological characteristics, as well as their biological behavior. It also highlights the fact that, although the patients underwent a number of surgeries and have faced innumerous complications, they lived long, and with a good quality of life.

Serviço de Neurocirurgia do Hospital dos Servidores do Estado, Rio de Janeiro RJ - Brazil: ${ }^{1}$ Head; ${ }^{2}$ Resident; ${ }^{3}$ Pathologist.

Received 28 April 2008, received in final form 30 July 2008. Accepted 8 August 2008.

Dr. José Carlos Lynch - Rua Jardim Botânico 600/605 - 22461-000 Rio de Janeiro RJ - Brasil. E-mail: cneuroamericas@uol.com.br 
Table. Demographic, clinical histological data.

\begin{tabular}{|c|c|c|c|c|c|c|c|}
\hline Case & Age-sex & Location & $\begin{array}{c}\text { Radio. } \\
\text { Post }\end{array}$ & $\begin{array}{c}\text { Radio. } \\
\text { Pre }\end{array}$ & $\operatorname{Vol}\left(\mathrm{cm}^{3}\right)$ & $\begin{array}{c}\text { NNo of } \\
\text { operations }\end{array}$ & Histology \\
\hline \multirow[t]{7}{*}{1} & $48-\mathrm{Fe}$ & Parag. F (2) & Yes & No & 48 & 5 & Grade I \\
\hline & & $\mathrm{F}$ & & & 3 & & Transitional \\
\hline & & $\mathrm{F}$ & & & 7.5 & & \\
\hline & & $\mathrm{F}$ & & & 6.7 & & \\
\hline & & $P$ & & & 6 & & \\
\hline & & & & & 8 & & \\
\hline & & & & & 12 & & \\
\hline \multirow[t]{6}{*}{2} & $50-M$ & FP & No & Yes & 192 & 3 & Grade I \\
\hline & & Tent R & & & 24.3 & & Transitional \\
\hline & & FR & & & 8 & & Fibroblastic \\
\hline & & S Caver & & & 2 & & \\
\hline & & FL & & & 4 & & \\
\hline & & TR & & & & & \\
\hline \multirow[t]{2}{*}{3} & $42-\mathrm{Fe}$ & Sph R and L & Yes & No & 175 & 2 & Grade I \\
\hline & & & & & 150 & & Transitional \\
\hline \multirow[t]{2}{*}{4} & $55-\mathrm{Fe}$ & $\mathrm{F}$ & No & No & 115.5 & 3 & Grade I \\
\hline & & $R$ and $L$ & & & 127.5 & & \\
\hline \multirow[t]{3}{*}{5} & $56-M$ & FR and $L$ & Yes & No & 130 & 2 & Grade II \\
\hline & & & & & 150 & & Meningoteliomatous \\
\hline & & & & & 125 & & \\
\hline \multirow[t]{2}{*}{6} & $42-\mathrm{Fe}$ & FR & No & No & 6 & 1 & Grade I \\
\hline & & Sph & & & 12 & & Meningotelial \\
\hline \multirow[t]{2}{*}{7} & $84-\mathrm{Fe}$ & Parag $R$ and $L$ & No & No & 72 & 1 & Grade I \\
\hline & & & & & 1.5 & & Fibroblastic \\
\hline
\end{tabular}

Cav, cavernous; F, frontal; Fe, female; FP, fronto-parietal; L, Left; M, male; Parag, parasagittal; Post, postoperative; Pre, preoperative; R, right; Radio, radiotheraphy; S, sinus; Sph, sphenoidal; T, temporal; Tent, tentorial; Vol, volume.

\section{METHOD}

Between 1986 and 2006, 7 patients with multiple intracranial meningiomas were diagnosed and treated at Servidores do Estado Hospital and at Copa D'Or Hospital (RJ). The present study carried out a retrospective review, which included analysis of patients' records, surgical descriptions, imaging studies, and histopathological material reviewed by a sole pathologist, confirming the diagnosis of meningioma in all the cases.

\section{RESULTS}

The patients' follow-up lasted from 1 to 21 years, (average of 11.7 years). This sample consisted of 5 women and 2 men, at a proportion of 2.5 women $/ 1$ man. The age varied from 42 to 84 (average 59). Twenty-two meningiomas of different sizes were identified, they varied from 1.5 to $192 \mathrm{~cm}^{3}$, with an average volume of $62.8 \mathrm{~cm}^{3}$. Eleven specimens were cortical, seven parasagittal, two meningiomas were located in the sphenoid wing, one of these penetrated the cavernous sinus. Other was tentorial and another derived from the sphenoid wing.

The number of tumors varied from 2 to 5 per patient. Microsurgical techniques were utilized to operate those tumors that needed surgical treatment. The number of procedures varied from 1 to 5 per patient. No surgical death occurred in this series. A 84-years-old female (case 7) died 3 months after surgery due to pneumonia. Case 2 had postoperative meningitis and 5 developed intracranial abscess. This case study showed, a high frequency rate of postoperative infections (16.6\%). We belive, this is due to the large number of surgeries and radiotherapy undergone by some patients, which causes deterioration of skin vascularization and of the bone flap (atrophic scar). It is also due to low immunity caused by the pathology itself or by continuous administration of corticosteroides. This finding was not acknowledged in literature. During this period, 3 cases of recurrence were observed

The demographic, clinical, histological data are presented in the Table.

\section{Significative cases}

CASE 1-A 48-year-old woman had been operated on to remove a left frontal parasagittal meningioma 5 years before our first evaluation. After two years, there was a local tumor recurrence. She was re-operated for a subtotal re- 


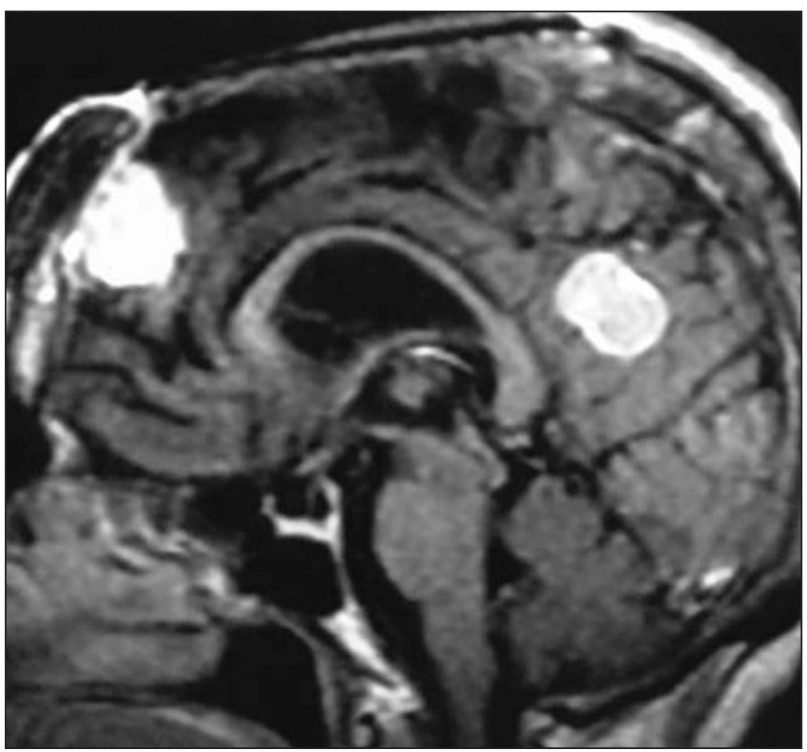

Fig 1. Patient 1. Post contrast $T 7$ weighted imaging showing one frontal and one parietal meningiomas, away from the previous craniotomies.

moval of the lesion, and following she underwent radiotherapy treatment. Three years later, she developed right hemiparesis. MRI detected bilateral parasagittal meningiomas, leading to complete occlusion of the superior longitudinal sinus. A new surgery removed the two lesions together with the superior sagittal sinus. Postoperative MRI confirmed the total removal of the lesions. Two years later, MRI revealed two new tumors in the right frontal area, distant from the implantation site of the previous meningiomas. With a frontal craniotomy, performed anterior to the previous craniotomies, a new thorough removal of both lesions was achieved. The patient's response was again satisfactory, as she could return to her daily house duties. Five years after the last intervention, two other meningiomas were identified. For the fifth surgery to be made, rotation of a pedicle flap was necessary due to poor vascularization of the surgical site and atrophic scar. The lesions were once again thoroughly removed. The postoperative follow-up was extended. At the moment, the patient presents light hemiparesis, which does not prevent her from living a normal life for her age. The last MRI showed the presence of two new meningiomas (Fig 1).

CASE 2 - A 50-year old man presented left hemiparesis with crural predominance. He informed that, when he was around 8-years- old, he underwent radiotherapy to treat tinea capitis. MRI revealed extra cerebral expansive process with clearly-defined contours, hyperintense, com heterogenic capitation of the contrast agent, located in the right parasagittal frontoparietal region and a second minor tumor implanted at the tentorium (Fig 2). A right fronto parietal craniotomy was performed, with the use of microsurgical techniques a complete removal of the tumor was achieved including the tumor implantation. The follow-up of the tentorial lesion with annual MRI, showed a progressive increase of the meningioma. A new surgical procedure was performed through a right occipital craniotomy, with complete removal of the lesion, and coagulation of the implantation site. He had meningitis in the early postoperative period and needed intravenous antibiotics treatment. When discharged from the hospital he had recovered from meningitis, but presented left homonymous hemianopsia. MRI performed approximately 3 years after the last surgery revealed frontal tumor recurrence and new tumor located in the cavernous sinus. He underwent right fronto-parietal craniotomy in the same surgical site of the previous one, and a complete removal of the lesion was again achieved (Fig 2). At the moment the MRI shows unchanged cavernous sinus lesion and two minor lesions appeared, in the left frontal and right temporal regions, with no surgical prescription at the moment.

\section{DISCUSSION}

The first description of a multiple intracranial meningioma was presented by Anfimov and Blumenau' ${ }^{12}$, in 1889, but Cushing and Eisenhardt ${ }^{1}$ were the ones to create a theoretical construct for this pathology. The multiple intracranial meningioma terminology should be used only when two or more meningiomas occur either simultaneously or in a sequence in different locations, but not necessarily of the same histological subtype. It is important to establish the difference between this pathology and tumor recurrence or diffuse meningiomatosis ${ }^{3,7,8}$.

Intracranial meningiomas incidence rate varies from 13 to $20 \%$. But MIM's are rare, when not associated with neurofibromatosis ${ }^{4-1,1,13}$.

The first quotations reveal an incidence of only 1 to $2 \%$. With the introduction of CT and MRI this incidence increased to 5.4 to $10.5 \% \%^{4-9}$. The incidence rate in our series was of $8.9 \%$, according to the figures found in the literature. None of our patients showed any sign of neurofibromatosis.

Meningiomas are rare during childhood and adolescence periods. They are more common during adult life ${ }^{1,2,3,6}$. In this case study, age varied from 42 to 84 (average of 57.5 years).

According to Black et al. there are some factors that are importants in the developing of the meningiomas ${ }^{14}$.

\section{Relevant etiological factors}

GENETICS - Deletion of the chromosome 22 in patients with type 2 neurofibromatosis and in up to $50 \%$ of solitary meningiomas are connected with the appearance of multiple meningiomas. 


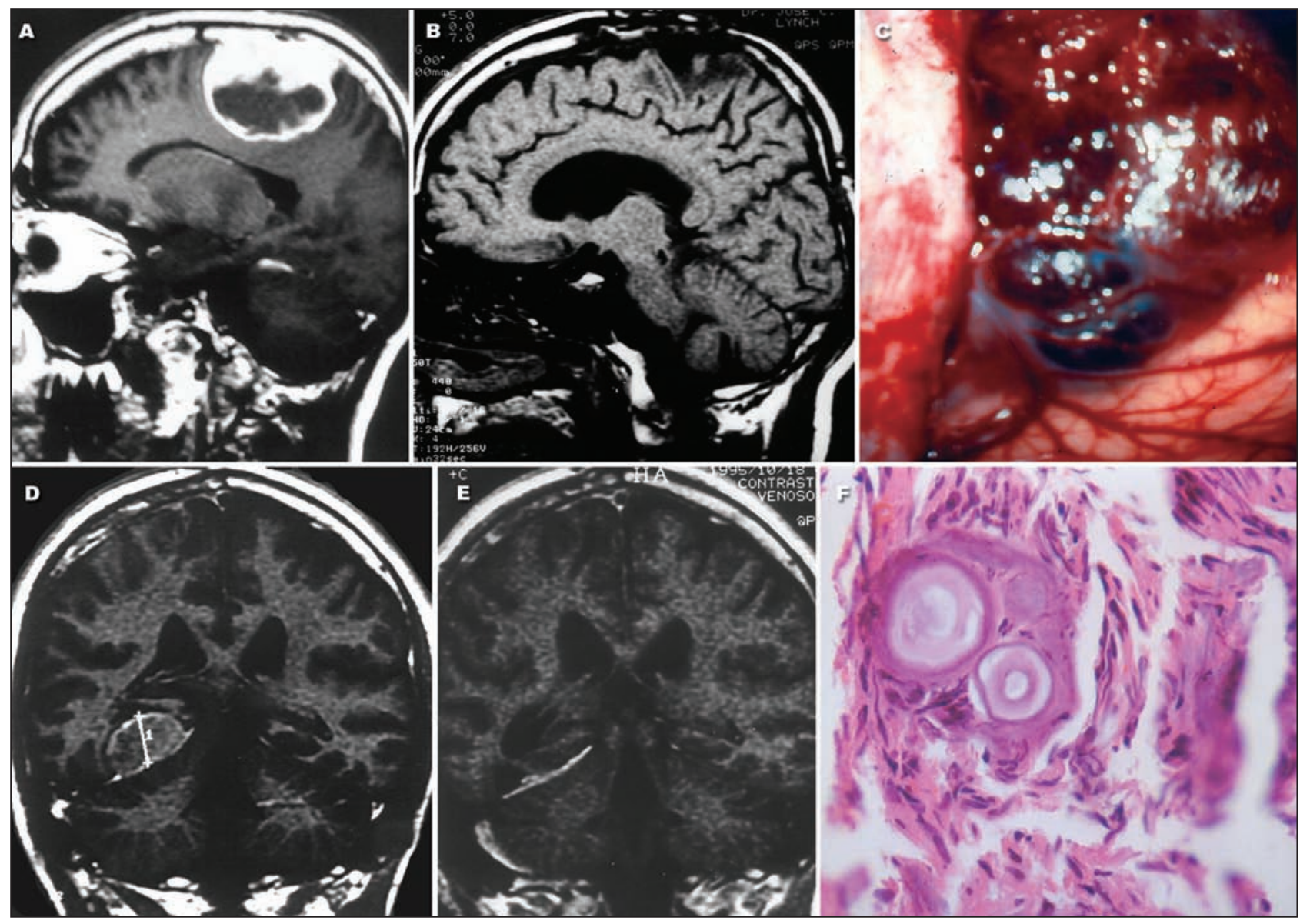

Fig 2. Patient 2. (A) Sagittal 71 post contrast image revealing heterogenic right parasagital tumor. (B) Intraoperatory photograph showing compressed brain parenchyma, a dark red tumor and duramater folded over superior sagital sinus. (C) Postoperative image confirming total tumor removal (Simpson 1). (D) Coronal T1 post contrast image demonstrating a tentorial meningioma. (E) Postoperative coronal T1 post contrast image confirming a complete tumor removal. Note the dural tail (Simpson 2). (F) Histology showing a benign meningioma (Grade I) with a psamoma body in the center of the picture (HEx 120).
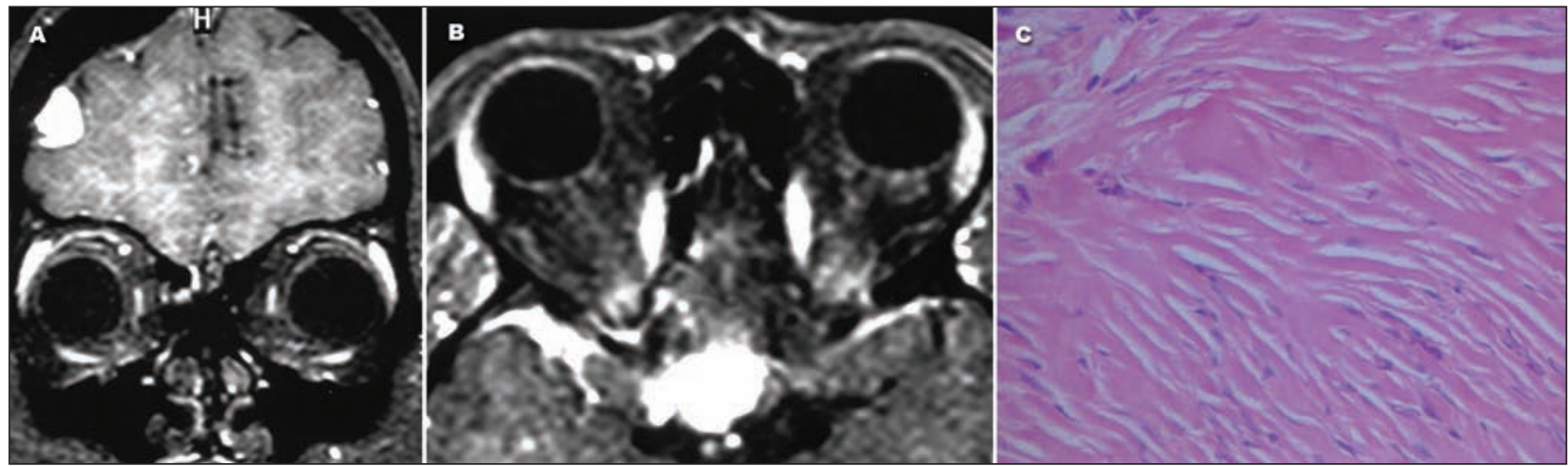

Fig 3. Patient 6. (A) Coronal post contrast T7 MRI demostranting a small, frontal meningioma. (B) Axial post contrast 77 imaging revealing a planun sphenoidal meningioma compresing the right optic nerve. Both tumors were removed through a single craniotomy. (C) Histology showing a beningn meningiomas of fibroblastic subtype. (HE x 120). 
IRRADIATION - There are a number of reports revealing the appearance of meningiomas after radiotherapy treatment. Approximately $30 \%$ of the cases presented by Harrison et al. were multiples meningiomas ${ }^{15-18}$. Even with a low-dose therapy, as the one used for children, for tinea capitis treatment ${ }^{19}$. This occurred with our patient 2 , who developed 5 meningiomas in adult life, after having undergone radiotherapy for tinea capitis treatment during childhood. Patient 1 underwent postoperative radiotherapy treatment after a partial meningioma removal. Some years later, she developed 4 successive recurrences. Aware of this risk, the use postoperative radiotherapy to inhibit tumor growth was prescribed exclusively for cases of partial removal with recurrence, as for example, meningiomas that invade the cavernous sinus, where total removal is rarely achieved and when so, is accompanied by morbidity, as it occurred with patient $3^{14,20,21}$.

HORMONES - A number of papers show a higher frequency rate of meningiomas in women. One factor associated is the action of progesterone in progesterone receptors found in $80 \%$ of meningiomas, leading to an increase during the luteal phase of the menstrual cycle and during pregnancy ${ }^{22-26}$. A proportion of 2.5 women to 1 man was observed in the present series.

TREATMENT - Each tumour should be individually assessed. Surgery is planned and performed aiming at total removal of the symptomatic lesion. An asymptomatic small meningioma without cerebral edema should be followed-up with MRI every 6 or 12 months, mainly if the patient is more than 65 years old. Surgery should be prescribed exclusively for cases with tumor expansion, symptoms appearance or cerebral edema ${ }^{6,14,27}$. The above described strategy was utilized to the patients involved in this study.

If, otherwise, both tumors are located close to each other and can be approached by a single craniotomy, it is advisable that both lesions be removed, including the asymptomatic tumor, as it occurred with Patient $6^{7,9,22}$ (Fig 3). The meningiomas surgical treatment should always aim at their complete removal, as well as their dural implantation, thus decreasing recurrence possibilities, and improving the patient's chances of healing ${ }^{2,7,8}$. This above concept originates from Simpson et al. conclusions ${ }^{28}$, which established a correlation between tumor removal extension and recurrence.

Our department's elected procedure is always to plan and perform surgery aiming at total exeresis of the meningiomas and of their dural implants. When this is not possible, bipolar coagulation at the implant site is performed with the objective of achieving grade II of Simpson's classification. The grade I or II was achieved with all the tumors, except for a meningioma which invaded the cavernous sinus (Patient 3).

Another important factor related to tumor recurrence and prognosis is the histological classification defined by World Health Organization (WHO). The grade of the histological classification has implications for tumor invasion and recurrence. The following grades were established by the WHO:

- Grade I: Benign meningiomas (85-90\%) include meningoendotelial, fibroblastic, transitional, psammomatous, angiomatous, microcystic, and metaplasic meningiomas. These characteristics of the sub-group are not relevant for the prognosis. They are mere descriptions of different histology.

- Grade II: Atypical meningiomas (5-10\%), more aggressive.

- Grade III: Malignant meningiomas (3-5\%).

Except for one tumor (Case 5) classified as atypical, all the other meningiomas fit in Grade I WHO's histological scale. Three tumor recurrences were observed in these series.

Aiming at assessing the treatment results, we used Glasgow's outcome scale. There was no operative mortality in this series. There was one death, due to pneumonia, 3 months after surgery. All the other patients showed a positive response to the treatment performed, and were classified in grade 4 or 5 , according to the Glasgow outcome scale. Follow-up varied from 1 to 21 years, (average of 11.7 years).

In conclusion, multiple intracranial meningiomas are a rare pathology. The multiple intracranial meningioma terminology should be used only when two or more meningiomas occur either simultaneously or sequentially in different locations. The goal of surgical treatment is to achieve grade I or II of Simpson's classification. Despite the multiplicy of tumors, number of recurrences, and the novo tumors, repeated operations and reoperations, radiotherapy and a number of postoperative complications, the patients experinced a long survival in conjunction with a fairly good quality of life.

\section{REFERENCES}

1. Cushing H, Eisenhardt L. Meningiomas: their classification, regional behaviour, life history and surgical end results. Springfield: Charles C. Thomas, 1938:115-132.

2. Zülch KJ. Brain tumors: their biology and pathology. New York: Springer 1965: 202-214.

3. Russel DS, Rubinstein LJ. Pathology of tumors of the nervous system. Baltimore: Williams and Wilkins, 1977:65.

4. Butti G, Assietti R, Casalone R, Paoletti P. Multiple meningiomas: a clinical, surgical and cytogenetic analysis. Surg Neurol 1989;31:255-260.

5. Nahser HC, Grote W, Löhr E, Gerhard L. Multiple meningiomas: clinical and computed tomographic observations. Neuroradiol 1981;21: 259-263. 
6. Sheehy JP, Crockard HA. Multiple meningiomas: along-term review. J Neurosurg 1983;59:1-5.

7. Turgut M, Palaoglus S, Ösmam OE, Gurçay G. Multiples meningiomas of the central nervous system without the stigmata of neurofibromatosis: clinical and therapeutic study. Neurosurg Rev 1997;20:117-123.

8. Santos JAN, Andrade D, Andrade V, Novaes V. Meningiomas múltiplos: apresentação de três casos. Arq Bras Neurosurg 1995;14:96-101.

9. Levin P, Gross SW, Malis LI, Kirshenbaum AH, Hollin SA. Multiple intracranial meningiomas. Surg Gyneg Obstet 1964;119:1085-1090.

10. Mufson JA, Davidoff LM. Multiple meningiomas: report of two cases. J Neurosurg 1944;1:45.

11. Bonnal J, Born JD, Tremoulet M. Meningiomes multiples intracraniens. Neurochirurgia 1979;25:78-83.

12. Anfimow J, Blumenau L. Ein fall multipler geschwülste in der Schadelhöle. Neurol Zetralbl 1889;8:585.

13. Evans DGR, Watson C, King A, Wallace AJ, Baser ME. Multiple meningiomas: differential involvement of the NF 2 gene in children and adults. J Med Genet 2005;42:45-48.

14. Black P, Morokoff A, Zauberman J, Claus E, Carroll R. Meningiomas: science and surgery. Clin Neurosurg 2007;54:91-99.

15. Barbosa ES, Panagopoulos AT, Lancelloti LP, Veiga JCT. Meningioma pós-radioterapia. Arq Neuropsiquiatr 2006;64:794-797.

16. Longstreth Jr WT, Dennis LK, McGuire VM, Drangsholt MT, Koepsell TD. Epidemiology of intracranial meningioma. Cancer 1993;72:639-648.

17. Harrison MJ, Wolfe DE, Lau T, Mitnick RJ, Sachdev VP. Radiation-induced meningiomas: experience at Mount Sinai Hospital and review of the literature. J Neurosurg 1991;75:564-574.
18. Sadamori N, Shibata S, Mine M, et al. Incidence of intracranial meningioma in Nagasaki atomic-bomb survivors. Int J Cancer 1996;67:318-322.

19. Sadetzki S, Flint-Richter P, Ben-Tal F, Nass D. Radiation-induced meningioma: a descriptive study of 253 cases. J Neurosurg 2002;97:1078-1082.

20. Maruyama K, Masahiro S, Kurita H, Kawahara N, Morita A, Kirino T. Proposed treatment strategy for cavernous sinus menigiomas: a prospective study. Neurosurg 2004;55:1068-1075.

21. Pham CJ, Chang SD, Gibbs IC, Jones P, Heilbrun MP, Adler jr JR. Preliminary visual field preservation after staged cyberknife radiosurgery for perioptic lesions. Neurosurgery 2004;54:799-811.

22. Gruber T, Dare AO, Balos LL, Lele S, Fenstermaker RA. Multiple meningiomas arising during long term therapy with the progesterone agonist megestrol acetate. J Neurosurg 2004;100:328-331.

23. Lynch JC, Emmerich JC, Kislanov S, et al. Tumor cerebral e gravidez. Arq Neuropsiquiat 2007;65:1211-1215.

24. Grumberg SM, Daniels AM, Muensch H, et al. Correlation of meningioma hormone receptor status with hormone sensitivity in tumor stem cell assay. J Neurosurg 1987;66:405-408.

25. Blaaw G, Blankenstein MA, Lamberts SW. Sex steroid receptors in human meningiomas. Acta Neurochir (Wien) 1986;79:42-47.

26. Markwalder TM, Zava DT, Goldmirsch A, Markwalder RV. Estrogen and progesterone receptors in meningiomas in relation to clinical and pathologic features. Surg Neurol 1983;20:42-47.

27. Nakamura M, Roser F, Michel J, Jacobs C, Samii M. The natural history of incidental meningiomas. Neurosurg 2003;53:62-71.

28. Simpson $\mathrm{D}$. The recurrence of intracranial meningiomas of the surgical treatment. J Neurol Neurosurg Psychiatry 1957;20:22-39. 